\title{
A Case of Delayed Diagnosis of Small Cell Carcinoma Originated from the Maxillary Sinus with Bilateral Fungal Sinusitis
}

\author{
Beom Mo Koo ${ }^{1}$, Hyung Gu Kim ${ }^{2}$, HyunSang Cho ${ }^{1}$, and Pona Park ${ }^{3}$ \\ ${ }^{1}$ Department of Otorhinolaryngology-Head and Neck Surgery, Veterans Health Service Medical Center, Seoul; and \\ ${ }^{2}$ Department of Otorhinolaryngology-Head and Neck Surgery, Hanyang National University Guri Hospital, Guri; and \\ ${ }^{3}$ Department of Otorhinolaryngology-Head and Neck Surgery, National Police Hospital, Seoul, Korea
}

\author{
양측 진균성 부비동염을 동반하여 진단이 지연된 상악동 소세포암 1예 \\ 구범모 $^{1} \cdot$ 김형규 $^{2} \cdot$ 조현상 $^{1} \cdot$ 박보나 $^{3}$ \\ 중앙보훈병원 이비인후과, ${ }^{1}$ 한양대학교 구리병원 이비인후과, ${ }^{2}$ 국립경찰병원 이비인후과 ${ }^{3}$
}

\author{
Received September 25, 2019 \\ Revised December 19, 2019 \\ Accepted December 20, 2019 \\ Address for correspondence \\ Pona Park, MD \\ Department of Otorhinolaryngology- \\ Head and Neck Surgery, \\ National Police Hospital, \\ 123 Songi-ro, Songpa-gu, \\ Seoul 05715 , Korea \\ Tel $+82-2-3400-1274$ \\ Fax $+82-2-400-0287$ \\ E-mailvvalse01@naver.com
}

Extrapulmonary small cell carcinoma originated from the paranasal sinus is extremely rare, and its local and distant metastasis is common and the prognosis is poor. We recently experienced a rare case of small cell carcinoma that originated from the maxillary sinus. However, the diagnosis was delayed for several reasons, one of which included accompanied bilateral fungal sinusitis. The patient received chemotherapy for four times, but the therapy was discontinued due to poor general conditions. We report our case with a review of the literature.

Korean J Otorhinolaryngol-Head Neck Surg 2020;63(6):276-81

Key Words Aspergillosis · Maxillary sinus · Small cell carcinoma.

\section{서 론}

소세포암은 신경내분비성 종양의 하나로 고등급 저분화도 의 분열이 빠른 특징을 가지며 악성도가 높고 주로 폐에서 원 발한다. 폐외소세포암은 전체 소세포암의 $4 \%$ 정도를 차지하 고, 조직학적 소견은 폐에서 발생한 경우와 큰 차이가 없으나 임상적으로 국소 재발이 흔하며 침습적이라 예후가 불량하 다고 알려져 있다.1) 주로 위장관계 및 흥선에서 발견되고 드 물게 두경부 영역에서도 발견되나 주로 후두에서 발생하고, 부비동에서 발생하는 경우는 해외에서 1965년 Raychowdhuri ${ }^{2}$ 에 의해 처음 보고되었으며, 국내에서는 상악동에서 발

This is an Open Access article distributed under the terms of the Creative Commons Attribution Non-Commercial License (https://creativecommons.org/licenses/by-nc/4.0) which permits unrestricted non-commercial use, distribution, and reproduction in any medium, provided the original work is properly cited.
생한 폐외소세포암종이 2예 ${ }^{3,4}$ 보고되어 있다.

저자들은 최근 좌측 상악동에서 발생한 폐외소세포암 1예 를 치험하였다. 그러나 초기 비증상이 없고, 양측 진균성 부 비동염을 동반하는 등 여러 가지 원인으로 진단이 지연되었 다. 이에 문헌 고찰과 함께 증례를 분석하여 보고하는 바이다.

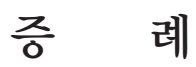

64세 여자 환자가 내원 5주 전 외부 치과에서 치아 신경치 료를 받던 중 좌측 상 잇몸 및 안면 부종이 발생하여 콘빔 전 산화단층촬영을 시행하고 절개 배농을 시도하였으나 실패하 였다. 이에 영상상 발견된 부비동염 소견으로 타 외래에서 내 원 2주 전 부비동 전산화단층촬영을 시행 후 양측 상악동 부 비동염 의심 소견으로 내원하였다. 환자는 기저질환으로 고 
혈압, 당뇨 외 1992년 난소암으로 자궁전적출술 및 양측 난소 절제술 후 cyclophosphamide, adriamycin, cisplatin 3제 복 합화학요법, 2003년에 유방암으로 절제 생검을 받은 과거력이 있었으며, 흡연력은 없었고, 가족력상 특이 소견은 없었다. 내 원 당시 환자는 코 불편감을 호소하지 않았으며, 약간의 압통 을 동반한 좌측 안면 부종 및 구강 시진상 좌측 제 1,2 소구 치 주위 부종 소견(Fig. 1)을 보였으며, 비강 내시경상 좌측 비중격 만곡 외에 특이 소견은 없었다. 부비동 전산화단층촬 영에서 양측 상악동에 골 점막 비후 및 연조직 음영을 동반한 석회화 소견이 관찰되었으나, 골 파괴 소견은 관찰되지 않았 다(Fig. 2). 이에 환자에게 양측 상악동 진균성 부비동염 의심 소견에 대한 수술적 치료의 필요성을 설명하였으나 환자는 치과 치료 후 발생한 좌측 안면 부종에 대한 우선적인 치료를

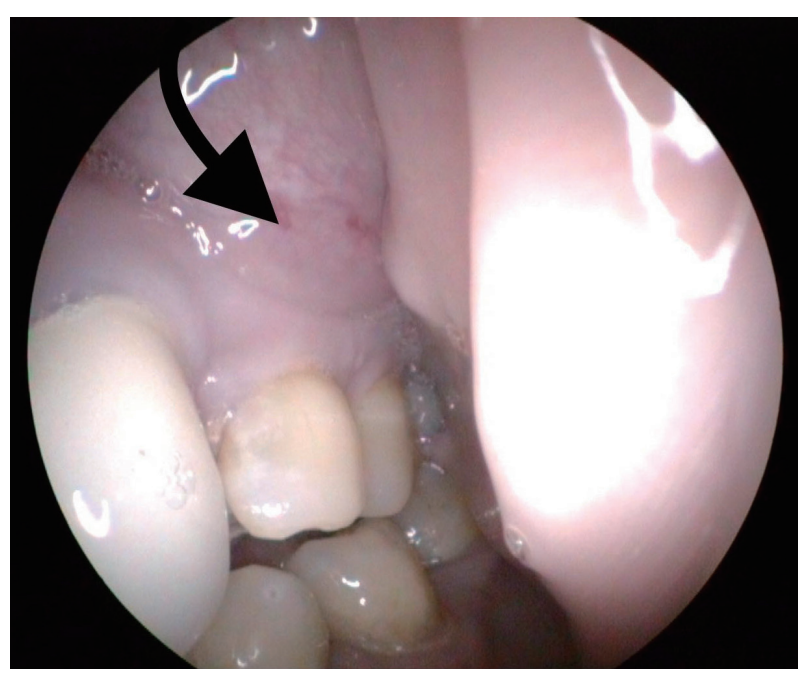

Fig. 1. Swelling of vestibular mucosa around left upper first and second premolar teeth (arrow).
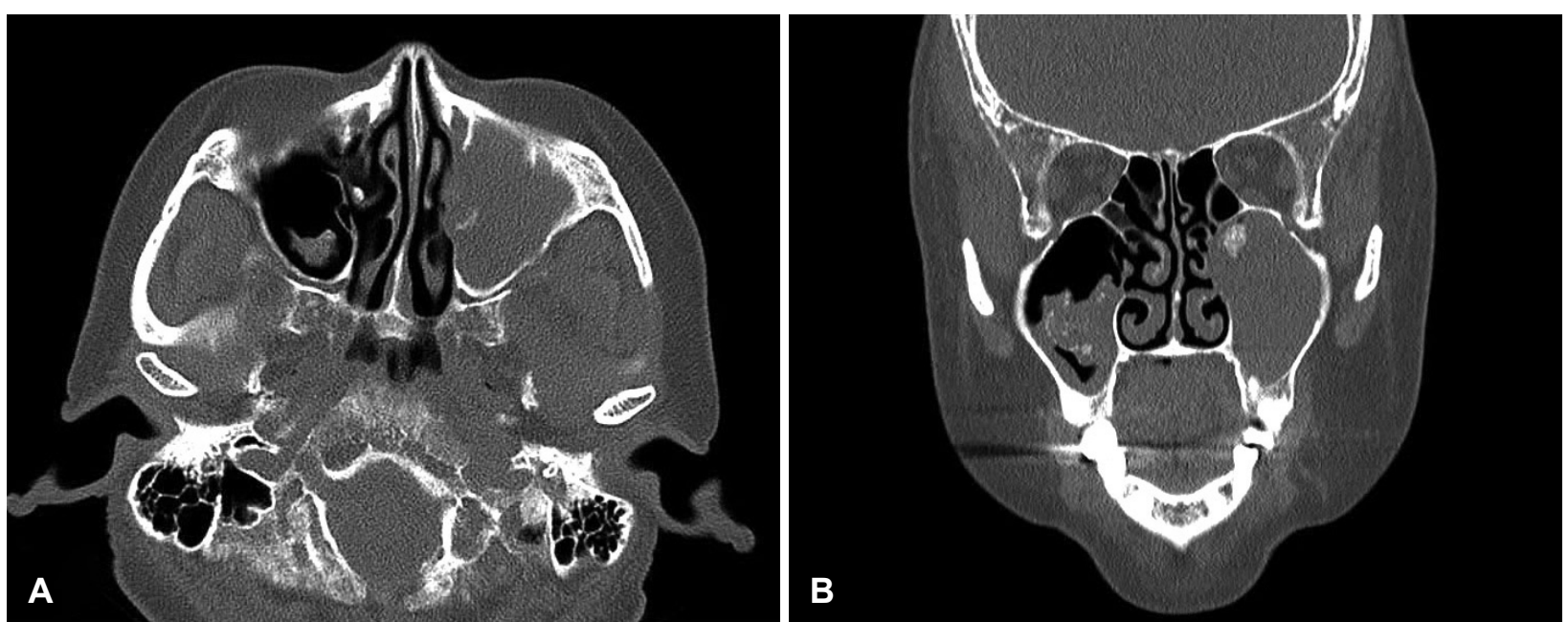

Fig. 2. Axial (A) and coronal (B) paranasal sinus $C T$ scan. Periosteal mucosal thickening in the both maxillary sinus, and calcification in both maxillary sinus without bony destruction.
강력히 원하였고, 이에 치성 농양을 의심하에 본원 구강외과 에 진료를 의뢰하였다. 이후 본원 구강외과에서 25 번 치아 주 위로 3 번의 절개 및 배농으로 고름과 다량의 육아조직을 제 거하고 항생제 치료를 하였으나 호전과 악화를 반복하였다. 6주 후 좌측 협측골의 누공이 상악동 내로 연결된 소견이 추 가로 관찰되어 이비인후과로 다시 의뢰되었다. 재진료 시 여 전히 코 불편감은 없었으나 좌측 안면 부종은 더욱 악화되었 고, 비강 내시경상 좌측 중비도에 약간의 부종 소견을 보였다. 이에 양측 중비도 개창술을 계획하였다. 우선 우측 중비도 개 창술 후 진균구로 의심되는 갈색의 석회화된 병변을 제거하 였고, 이어서 좌측 중비도 개창술을 시행하였는데 진균구 의 심 병변과 함께 매끈한 표면의 다소 견고한 연조직이 상악동 내부를 가득 채우고 있었다. 동결절편검사 결과, 해당 조직이 소세포암임이 진단되어 가능한 한도 내에서 미세절삭기를 이용해 일부 제거 후 수술을 종료하였다. 최종 조직검사 결과 hematoxylin \& eosin 염색에서 세포질이 적고 핵이 과염색 되는 원형 및 방추형의 작은 세포가 관찰되었으며(Fig. 3A), 면역조직화학염색상 cytokeratin(Fig. 3B), CD56(Fig. 3C), $\operatorname{synaptophysin(Fig.~3D)ㅇㅔ~ㅇㅑㅇㅅㅓㅇㅇㅡㄹㅗ~ㅍㅖㅇㅚㅅㅗㅅㅔㅍㅗㅇㅏㅁㅇㅡㄹㅗ~ㅈㅣㄴㄷㅏㄴ~}$ 되었다. 추가적으로 진균구에 대한 hematoxylin \& eosin 염 색상 균사는 아스페르길루스종으로 확인되었다(Fig. 3E).

술 후 당일 시행한 조영 증강 경부 전산화단층촬영에서 좌 측 상악동, 상악동 앞쪽 부위 및 협부 점막에 걸쳐 조영이 증 강되는 $5.5 \mathrm{~cm}$ 연조직 종괴가 관찰되었고(Fig. $4 \mathrm{~A})$, 좌측 측 경부와 인두후부에 다수의 림프절 전이 소견이 관찰되었다 (Fig. 4B). 조영 증강 부비동 자기공명영상촬영에서는 동일 부위에 $\mathrm{T} 2$ 강조영상에서 중간 신호 강도를 보이고(Fig. 5A), $\mathrm{T} 1$ 에서 저신호 강도를 보이며, 조영제를 사용한 $\mathrm{T} 1$ 강조영상 

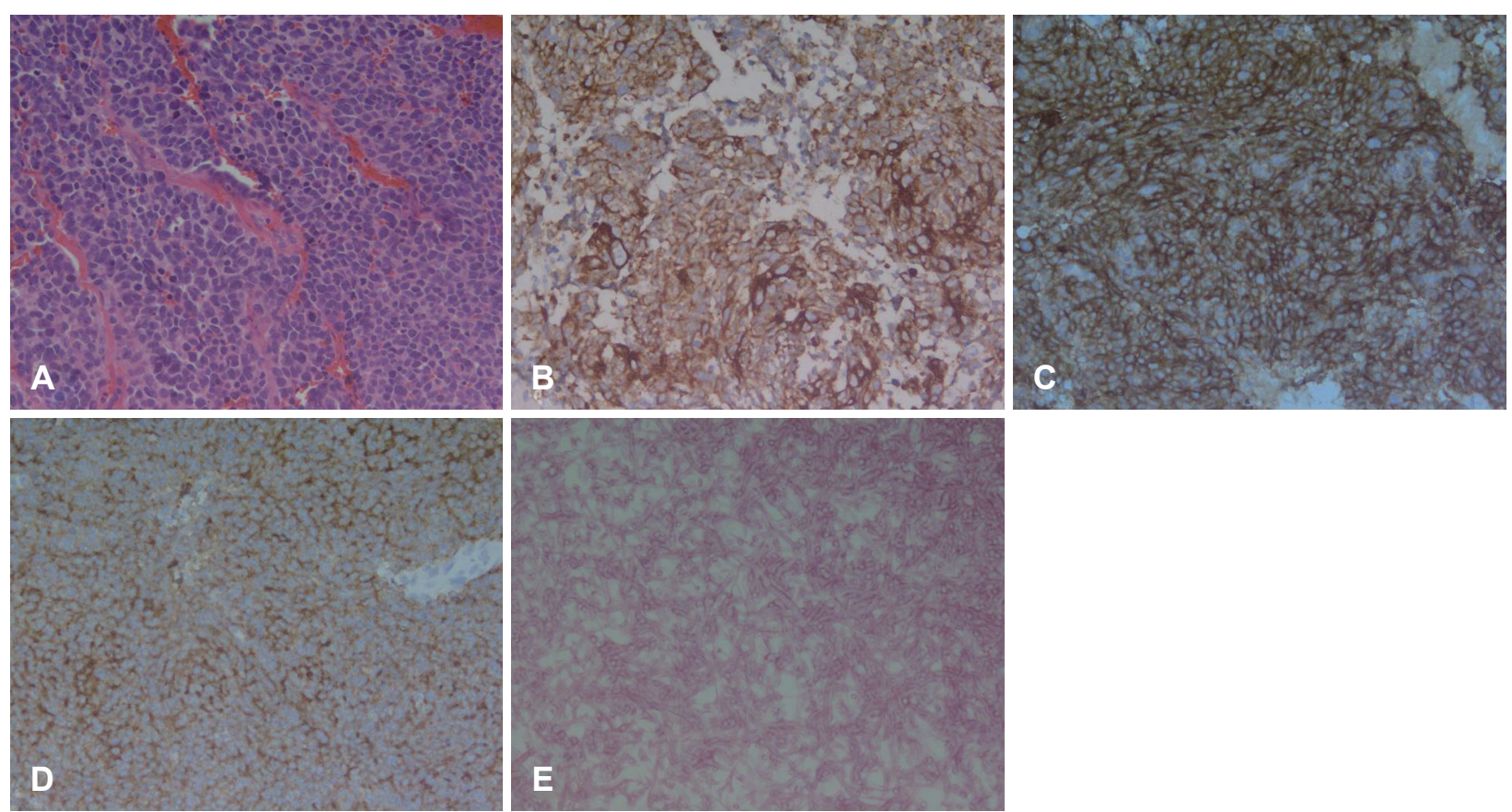

Fig. 3. Histopathologic and immunohistochemically study findings. Round and spindle shaped small cell with hyperchromatic nuclei and scanty cytoplasm (H\&E stain, $\times 200)(A)$. Positive stain for cytokeratin $(\times 200)(B)$, CD56 $(\times 200)(C)$, synaptophysin $(\times 200)(D)$. Staining for aspergillus fungus ball (H\&E stain, $\times 400)(E)$. H\&E: hematoxylin \& eosin.
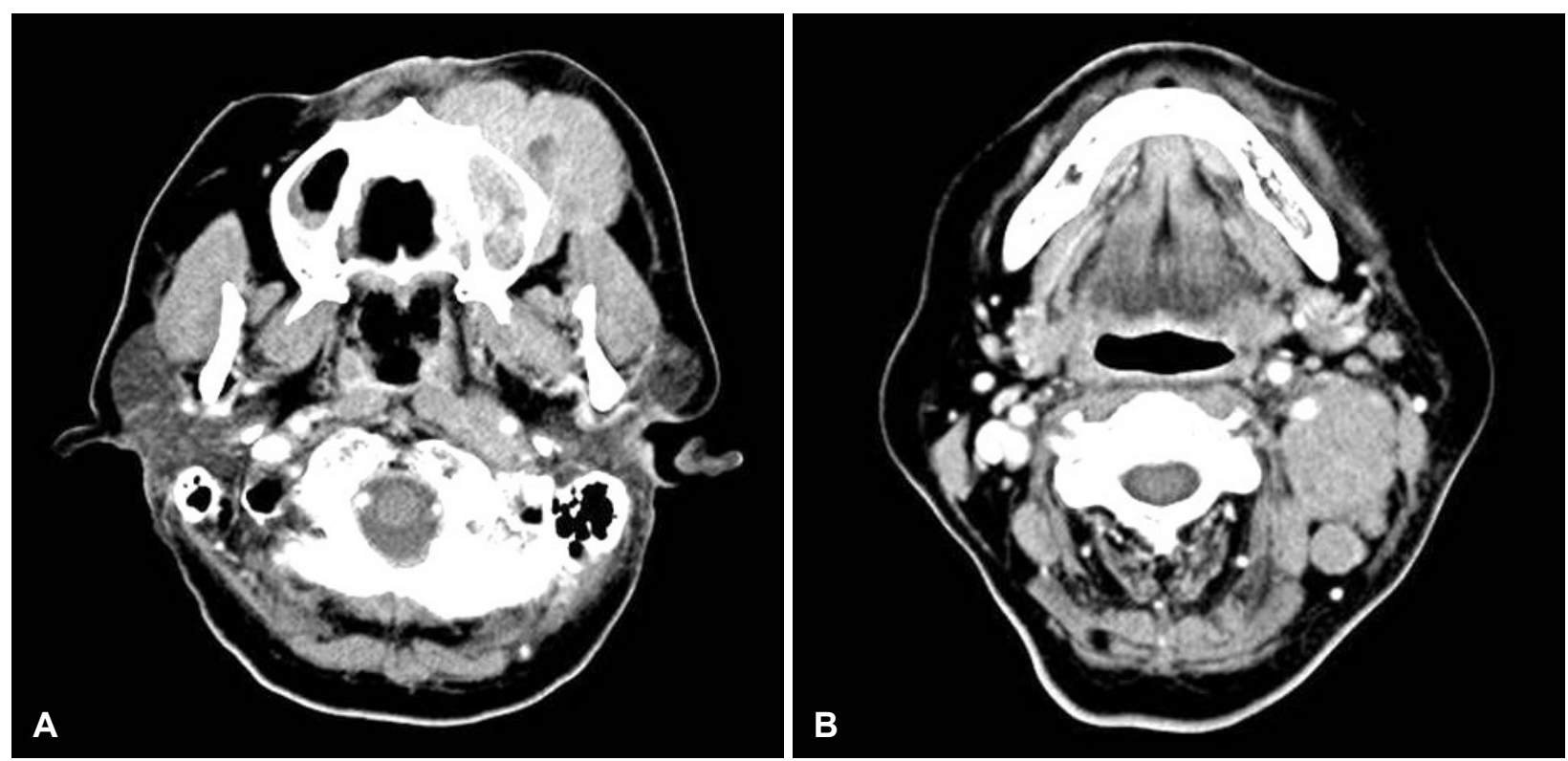

Fig. 4. Post-operative enhanced neck CT axial scans. Enhanced soft tissue lesion, $5.5 \mathrm{~cm}$, involving left maxillary sinus, pre-maxillary region, buccal region $(A)$, and multiple enlarged lymph nodes in the left lateral neck space (B) are found.

에서 조영 증강되는 연조직 종괴를 확인하였다(Fig. 5B). 술 후 5 일째 시행한 양전자방출단층촬영에서 좌측 상악동, 전 상악동 부위, 협부 점막 및 좌측 경부 림프절(Fig. 6A)에 fluorodeoxyglucose 섭취 증가와 함께 간과 비장(Fig. 6B)의 전 이 의심 소견이 보였다. 폐의 우상엽 부위에는 수술 당일 조 영 증강 경부 전산화단층촬영에서 보이지 않고 새롭게 관찰
되는, 염증성 결절 의심 소견이 있어 조영 증강 흥부 전산화 단층촬영을 추가로 시행하였고, 양성 병변이나 전암성 병변 배제 위해 3개월 뒤 추적 관찰을 권유받았다. 이에 최종 좌 측 상악동에서 기원한 폐외소세포암(cT4aN2bM1)으로 진단 되었다. 이후 환자가 원하여 항암 치료를 위해 타 병원으로 전원되었다. 

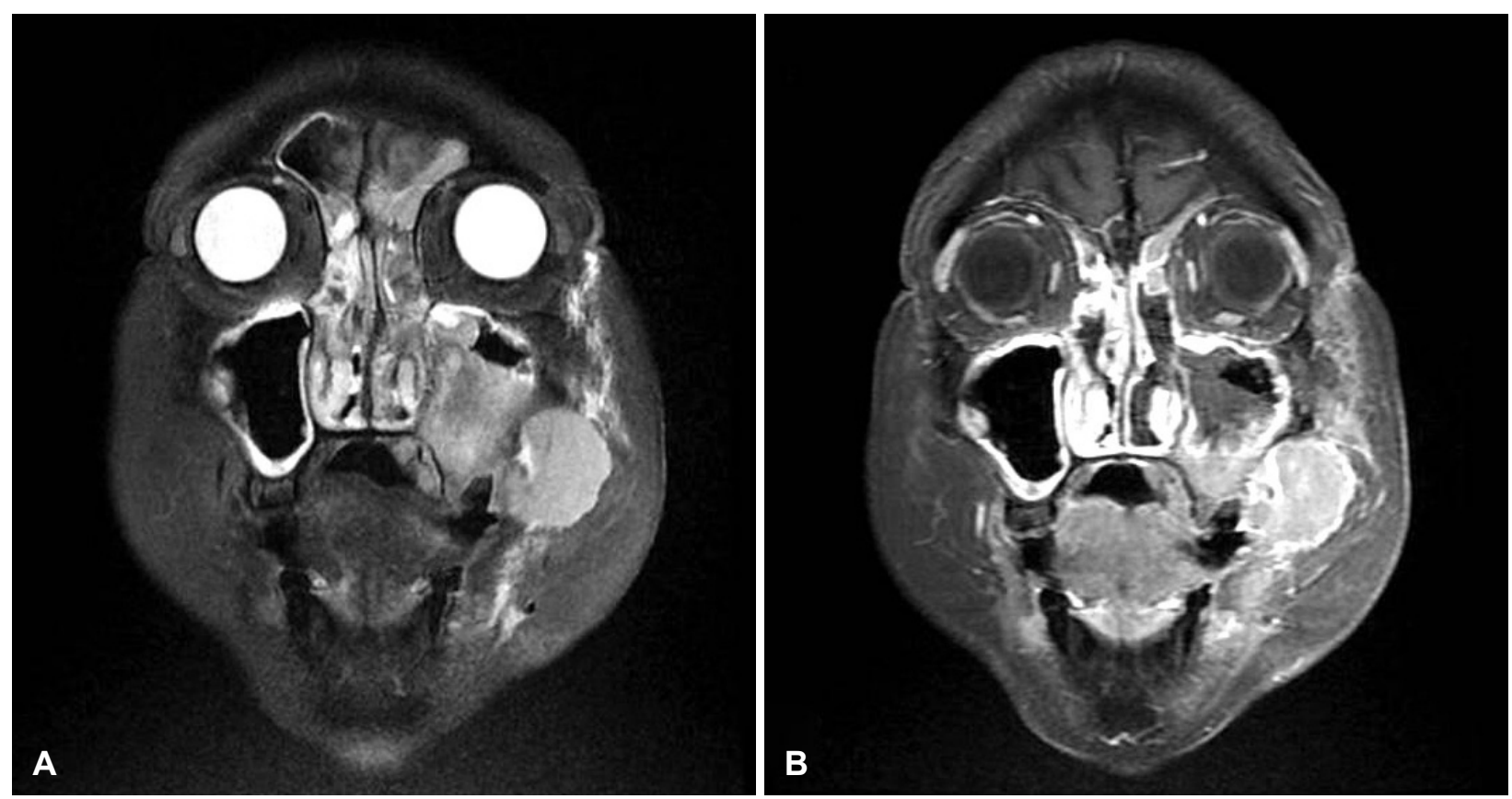

Fig. 5. Post-operative coronal paranasal sinus MR T2 weighted $(A)$ and $T 1$ enhanced $(B)$ images. $T 2$ weighted coronal image shows $5.5 \mathrm{~cm}$ soft tissue lesion with intermediate signal intensity involving left maxillary sinus and buccal region (A), and gadolinium-enhanced T1 weighted coronal image shows enhanced soft tissue mass in the same region (B).
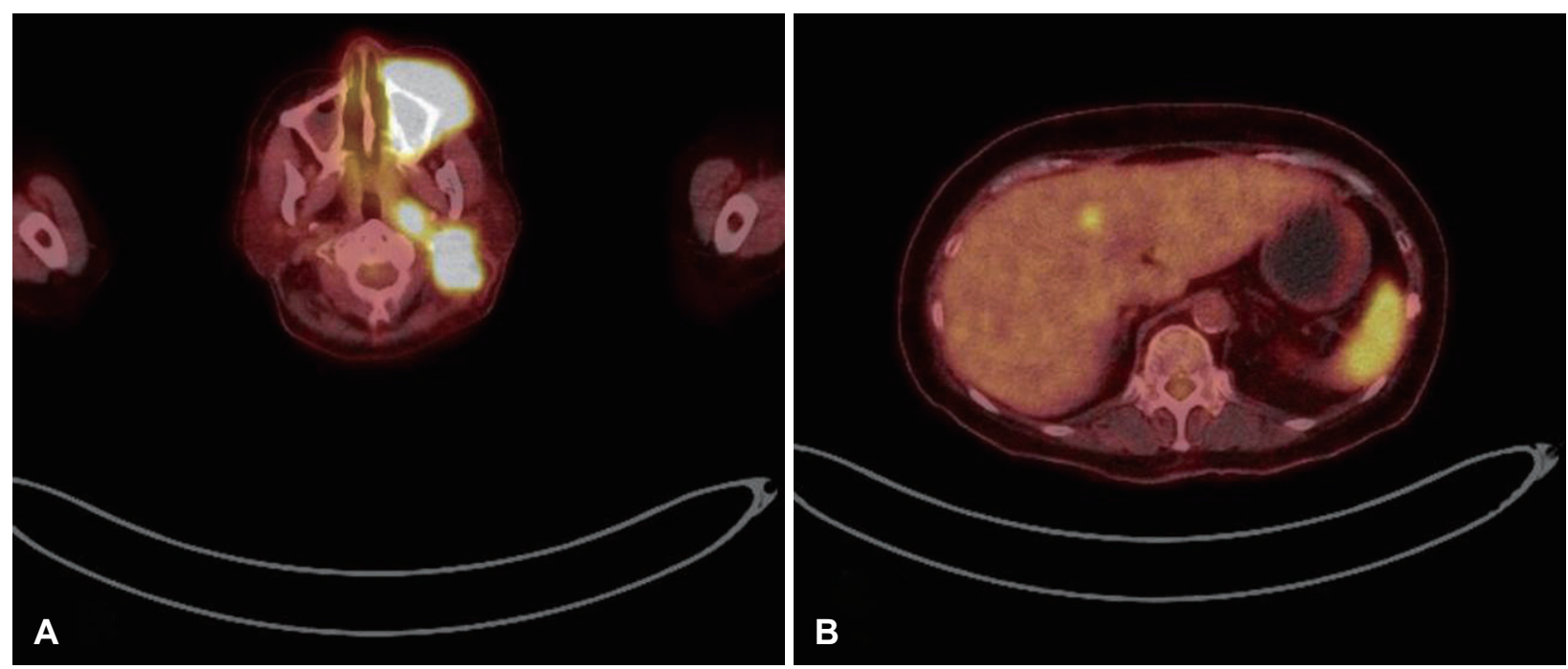

Fig. 6. Post-operative positron emission tomography-CT images. It shows hypermetabolic soft tissue mass on the left cheek with invasion of left maxillary sinus, pre-maxillary space, buccal region, and multiple metastatic lymph nodes in the left retropharyngeal space and level II (A). Focal area of increased FDG uptake in the S4 of the liver, and heterogeneously increased FDG uptake in the spleen are found (B). FDG: fluorodeoxyglucose.

이후 환자는 타 병원에서 etoposide와 cisplatin을 이용한 항암 치료를 4차례 시행받았고 부분 관해 소견을 보였으나, 폐 전이에 이은 폐렴 발생 등 환자의 전신상태 악화로 항암 화학요법은 중단되었고, 보존적 치료를 유지하며 술 후 9 개 월째 혼수상태로 생존 중이다.

\section{고 찰}

비강 및 부비동에 호발하는 종양은 조직학적으로 편평세 포암이 가장 흔하며, 그 뒤로 미분화암, 선양낭성암종, 선암, 흑색종 순으로 호발한다. ${ }^{5,6)}$

비부비동 영역에서 폐외소세포암이 발생한 경우는 극히 드

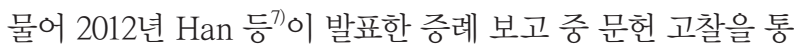


해 지난 40 여 년간 비부비동 영역에서 1 차성 폐외소세포암은 75예의 증례 보고가 있었다. 이 중 적절한 임상 및 병리학적 데이터가 이용 가능한 55예를 분석하여, 남녀 성비 $1.6: 1$, 평 균 발생 연령 51.3세, 사골동 및 상악동에 호발함을 보고하였 고, ${ }^{7)}$ 국내에서는 지금까지 비중격에서 1예,8) 상악동 2예, ${ }^{34)}$ 비 강 내 1 예" ${ }^{9}$ 가 보고되었다. 이 중 비중격에서 발생한 1 예 ${ }^{8}$ 의 경 우 종물 절제 후 확진되어 항암화학요법 6회 및 $5000 \mathrm{cGy}$ 의 방사선 치료 후 5년 동안 재발 없이 생존한 보고가 있으나, 나 머지 3개의 증례에서는 진단 당시 cT4aNOM0, ${ }^{3}$ cT4aN2M1, $\mathrm{cT} 4 \mathrm{bNOM}{ }^{9}$ 였으며, 병합 치료를 시행하였으나 치료 중 항암 화학요법의 합병증으로 사망하였다.

초기 증상으로 비폐색, 비루 및 반복되는 비출혈이 가장 흔 하나, ${ }^{10)}$ 이러한 증상은 다른 비강 내 발생하는 종양에서도 공 통적으로 발생하므로 진단에 어려움이 있을 수 있다. 본 증례 에서는 비증상이 없었고, 비강 내시경 소견도 정상이어서 초 기 진단에 어려움이 있었다.

폐외소세포암은 조기에 국소 및 원격 전이를 잘하고 예후 가 매우 불량하므로, 치료 시작 전에 전이에 대한 전신적 검 사가 필요하다. ${ }^{6}$ 본 증례의 경우 진단 시 이미 상악동, 전상악 동 및 협부 점막을 침범하고 경부 림프절 전이와 원격 전이가 동반된 상태였다.

폐외소세포암은 매우 드문 만큼 그 치료 방법이 정립되어 있지 않다. 소세포폐암의 경우 제한 병기에서는 항암화학요 법과 방사선 치료를 병행하고, 원격 전이가 있는 경우에는 항 암화학요법으로 치료하나, 폐외소세포암의 경우 1980년대까 지는 수술 후 방사선 치료가 주로 시행되었으나, 1990년대 후 반 이후로 항암화학요법, 방사선 치료, 수술적 치료, 단독 혹 은 병합 치료가 시행되고 있다. 항암 치료는 platinum 항암 제를 사용하며, etoposide와 cisplatin 병용 요법이 가장 많이 이루어지고 있다. ${ }^{11)}$ 본 증례에서도 etoposide와 cisplatin 병 용 요법을 사용하여 부분 관해에 도달하였으나 환자의 전신 상태 악화로 더 이상의 항암화학요법을 시행하지 못하였다.

폐외소세포암은 5년 생존율이 13\%로 매우 낮고, 원발 부 위에 따라 예후가 다른 보고가 있다. 특히 두경부 폐외소세포 암은 재발률과 전이율이 $33 \%$ 와 $31 \%$ 로 매우 높고 1년 생존 율과 5년 생존율이 각각 $57 \%, 10 \%$ 로 보고된 바 있으나, ${ }^{6}$ 증 례 자체가 희귀하여 좀 더 연구가 필요할 것으로 생각된다.

진균성 부비동염과 폐외소세포암이 공존하는 경우는 국내 에서 보고된 1예가 있다. ${ }^{3)}$ 해당 보고는 내원 시 우측 비강 내 종괴가 관찰되어 내시경하 절개 생검을 시행하던 중 진균구 가 발견된 증례이나, 본 증례에서는 전산화단층촬영상 의심 되는 양측성 진균성 부비동염으로 인해 수술을 시행하였고, 술 중 부비동 내 종괴가 발견되어 진단된 사례이다.
본 증례에서 원발 부위에 대한 논란이 있을 수 있다. 그러 나 폐의 우상엽의 병변은 수술 후 당일 시행한 조영 증강 경 부 전산화단층촬영에서는 관찰되지 않았고, 술 후 7일째 시 행한 조영 증강 흥부 전산화단층촬영에서도 염증성 병변과 감별을 요한다는 소견을 받았다. 그리고 폐 전이는 타 병원으 로 전원된 후에 확인되었던 점으로 미루어보아 상악동이 원 발 부위로 생각된다.

본 증례에서 진단이 늦게 이루어진 것에 대해서는 여러 가 지 원인이 있는 것으로 생각된다. 우선 환자의 주 증상인 안 면 부종에 대해서는 치과 신경치료 이후 발생한 점, 압통을 동반하고 있는 점, 본원 치과에서 배농 및 항생제 치료 후 일 부 호전이 있었던 점 등으로 미루어 우선적으로 치성 염증을 생각하였다. 그러나 내원 전 치과에서 시행한 절개 배농 시에 는 배액되는 것이 없었고, 본원 치과에서 치료 과정 중 육아 조직에 대한 조직병리검사를 시행하였으나 추가 염색으로 인 하여 확인이 늦어져 이비인후과 술전까지 진단이 미뤄졌다. 그리고 환자는 술 전까지 비폐색이나 비출혈 같은 비 증상이 없었고, 비강 내시경상 악성을 의심할 만한 특이 소견도 관찰 되지 않았다. 더군다나 환자가 강력하게 비과적 수술 치료를 거부하면서 추가적인 조치가 이루어지지 않았다. 또한 부비 동 전산화단층촬영에서 양측 상악동에 석회화가 관찰되고 골 미란이 동반되지 않아 악성 가능성을 크게 염두에 두지 않았고, 이에 추가적인 조영 증강 부비동 전산화단층촬영을 시행하지 않았던 점 등이 진단이 지연된 이유라고 생각된다.

앞서 말한 바와 같이 폐외소세포암은 조기에 국소 및 원격 전이를 잘하고 예후가 매우 불량하다. 본 증례에서도 전이가 급격하게 진행되어 항암화학요법 치료 중에도 폐로 전이되 었다.

본 증례에서 안면 부종 및 치성 농양의 의심 소견에 대해, 배농 및 항생제 치료가 이루어져 일시적인 호전이 있더라도 수주에 걸쳐 잘 낫지 않은 병변에 대해서는 악성이나 결핵 등 다른 진단 가능성을 염두에 두고 조기에 조영 증강 전산 화단층촬영이나 조직검사 등 추가적인 검사를 시행하는 것이 빠른 진단 및 치료에 도움이 되었을 것으로 생각된다.

\section{Acknowledgments}

None.

\section{Author Contribution}

Data curation: Hyung Gu Kim. Investigation: Beom Mo Koo. Project administration: Pona Park. Resources: Beom Mo Koo. Supervision: HyunSang Cho. Validation: Pona Park. Writing —original draft: Beom Mo Koo. Writing—review \& editing: Pona Park.

\section{ORCID}

Pona Park

https://orcid.org/0000-0002-3071-1730 


\section{REFERENCES}

1) Galanis E, Frytak S, Lloyd RV. Extrapulmonary small cell carcinoma. Cancer 1997;79(9):1729-36.

2) Raychowdhuri RN. Oat-cell carcinoma and paranasal sinuses. J Laryngol Otol 1965;79:253-5.

3) Yeo SC, Cho HJ, Kim SW, Jeon SY. A case of small cell carcinoma of the maxillary sinus coexisting with fungus ball. J Rhinol 2016; 23(2):110-4.

4) Ha SY, An HJ, Cho KW, Yoo CY, Cho JH, Kim SH, et al. A case of small cell carcinoma of the maxillary sinus with distant metastasis. Korean J Med 2015;88(6):719-23.

5) Renner G. Small cell carcinoma of the head and neck: A review. Semin Oncol 2007;34(1):3-14.

6) Babin E, Rouleau V, Vedrine PO, Toussaint B, de Raucourt D, Malard O, et al. Small cell neuroendocrine carcinoma of the nasal cavity and paranasal sinuses. J Laryngol Otol 2006;120(4):289-97.
7) Han G, Wang Z, Guo X, Wang M, Wu H, Liu D. Extrapulmonary small cell neuroendocrine carcinoma of the paranasal sinuses: A case report and review of the literature. J Oral Maxillofac Surg 2012;70(10):2347-51.

8) Kim YS, Bae CH, Song SY, Kim YD. A case of a small cell neuroendocrine carcinoma of the nasal septum. Korean $\mathrm{J}$ Otorhinolaryngol-Head Neck Surg 2009;52(6):529-32.

9) Kang JM, Lee HY, Lee KS, Ko SY. Small cell neuroendocrine carcinoma of the nasal cavity: A case report. Korean J Otorhinolaryngol-Head Neck Surg 2003;46(2):164-7.

10) Perez-Ordonez B, Caruana SM, Huvos AG, Shah JP. Small cell neuroendocrine carcinoma of the nasal cavity and paranasal sinuses. Hum Pathol 1998;29(8):826-32.

11) Kim KO, Lee HY, Chun SH, Shin SJ, Kim MK, Lee KH, et al. Clinical overview of extrapulmonary small cell carcinoma. J Korean Med Sci 2006;21(5):833-7. 